\title{
VERTĖS PASIŪLYMO ADAPTAVIMAS TIKSLINĖMS DARBUOTOJŲ GRUPE்MS DARBDAVIO PREKĖS ŽENKLO KŪRIMO KONTEKSTE
}

\author{
Gerda BERNATAVIČIŪTE்*, Asta RADZEVIČIENÉ \\ Vilniaus Gedimino technikos universitetas, Verslo vadybos fakultetas, Vadybos katedra, \\ Saulètekio al. 11, LT-10223 Vilnius, Lietuva \\ "El.paštas gerda.bernataviciute@gmail.com
}

\begin{abstract}
Santrauka. Darbdavio prekès ženklo kūrimas įvardijamas kaip veiksmingas strateginis ịrankis, siekiant pritraukti bei išlaikyti darbuotojus organizacijoje. Siekdama išskirti save iš konkurentų bei tapti pasirinktu darbdaviu, organizacija formuoja vertès pasiūlymą, kuris yra darbdavio prekès ženklo sudètinis elementas. Tačiau atliktas pilotinis empirinis tyrimas atskleidè, kad darbdavio vertès pasiūlymas yra beveik identiškas visu tyrime dalyvavusių organizacijų, todėl nebeveikia kaip darbdavio pozicionavimo įrankis. Dauguma ankstesnių tyrimų, susijusių su darbdavio prekès ženklo kūrimu, buvo nukreipti ị ịdarbinimo etapą. Dèl šios priežasties yra mažai žinoma, kas darbdavio prekès ženklą daro patrauklų esamiems darbuotojams. Vis dar pasigendama tyrimų, kuriuose vertès pasiūlymas būtų taikomas esamiems darbuotojams. Atsižvelgus ị skirtingų darbuotojų grupių profesinius bei asmeninius profilius ir jų poreikius, vertès pasiūlymo modifikavimas bei tikslingas pritaikymas, leistų padidinti darbdavio prekès ženklo veiksmingumą bei atnešti organizacijai ilgalaikès naudos. Vertès pasiūlymo adaptavimo esamiems darbuotojams tyrimas ir yra šio darbo tyrimo objektas.
\end{abstract}

Reikšminiai žodžiai: darbdavio prekès ženklas, vertès pasiūlymas, darbuotojų pritraukimas, darbuotojų išlaikymas, žmonių išteklių valdymas, organizacijos ịvaizdis.

\section{Ivadas}

Tyrimo aktualumas. Pasaulinės tendencijos žmogiškujų išteklių valdyme bei stiprejjanti konkurencija darbo rinkoje, atspindi darbdavių paieškas kurti produktyvų žmogiškaji potencialą organizacijoje. Dėl itin didèjančios darbuotojų kaitos bei talentingų darbuotojų trūkumo darbo rinkoje žmonių ištekliai tampa pagrindiniu ilgalaikio konkurencinio pranašumo šaltiniu. Siekiant sustiprinti organizacijos matomumą ir išskirtinumą, pritraukti ir išlaikyti darbuotojus, organizacijos skiria vis daugiau dèmesio darbdavio prekès ženklui. Kaip instrumentas konkuruoti šiandieninèje talentų rinkoje, darbdavio prekès ženklo kūrimo tikslas tiek organizacijos viduje, tiek išorẻje sukurti geidžiamo darbdavio ịvaizdị bei išsiskirti iš konkurentų. Darbdavio prekès ženklas - tai identifikuojama ir unikali darbdavio tapatybè. Darbdavio prekès ženklo kūrimo sudètinis elementas vertès pasiūlymas. Vertès pasiūlymas akcentuoja numatomą naudą, kurią potencialus darbuotojas gauna prisijungdamas prie organizacijos. Šalia to, vertès pasiūlymas turètų skatinti ir esamu darbuotojų išlaikymą organizacijoje, tačiau nėra pakankamai veiksmingai taikomas organizacijų veiklos praktikoje. Esamų darbuotojų išlaikymas ir darbuotojų kaitos mažinimas gali suteikti konkurencini pranašumą ugdant motyvuotų, ištikimų bei produktyvių darbuotojų bazę, kuri užtikrintų ilgalaikę darbdavio prekès ženklo sèkmę.

Tyrimo naujumas. Dauguma ankstesnių tyrimų, susijusių su darbdavio prekės ženklu, buvo nukreipti i įdarbinimo etapą, siekiant pritraukti potencialių darbuotojų bei sukurti patrauklios organizacijos ịvaizdi darbo ieškančio asmens požiūriu. Tačiau naujausia tyrimų kryptis yra darbdavio prekès ženklo patrauklumo esamiems darbuotojams tyrimai. Ši tema nèra plačiai analizuojama teorijoje, organizacijų praktikoje šis žmoniu ištekliu valdymo instrumentas taip pat nèra pakankamai veiksmingai naudojamas. Vienas aktualiausių klausimų yra, kokie vertès pasiūlymo modeliai yra taikytini esamų jaunų darbuotojų išlaikymui, trumpèjant vidutinei naujų specialistų darbo trukmei vienoje organizacijoje jų karjeros pradžioje. Pagrindinè tyrimo hipotezė yra, kad vyksta darbdaviụ teikiamų vertès pasiūlymų darbuotojams suvienodèjimas dèl kurio, vertès pasiūlymas neveikia kaip darbdavio konkurencinio pranašumo ịrankis. Nepakankamas vertės pasiūlymo adaptavimas skirtingoms tikslinėms grupėms, tai yra naujiems darbuotojams, patyrusiems specialistams, labai ilgai dirbantiems, ypatingai lojaliems bei kitiems ir dèl to tampa nebeveiksmingu. Antroji hipotezè, vertės pasiūlymo tikslinis modifikavimas, atsižvelgiant ị skirtingų darbuotojų grupių profesinius ir asmeninius profilius, leistų ženkliai padidinti šio įrankio veiksmingumą bei darbuotojų išlaikymą organizacijoje ilgesnį laiką. 
Tyrimo problema. Nepakankamas darbdavio prekès ženklo kūrimo sprendimų adaptavimas esamiems darbuotojams siekiant juos išlaikyti organizacijoje.

Darbo objektas - darbdavio vertès pasiūlymas esamiems darbuotojams kaip prekès ženklo formavimo elementas.

Tyrimo tikslas - identifikuoti vertės pasiūlymo tobulinimo sprendimus, kurie darbdavio prekės ženklą darytų patrauklesniu esamų darbuotojų atžvilgiu.

\section{Uždaviniai:}

- Išanalizuoti darbdavio prekės ženklo bei darbdavio vertès pasiūlymo sampratą;

- Pateikti vertès pasiūlymo struktūros analizès prieigą;

- Atlikti pilotinị empirini tyrimą, siekiant nustatyti darbdavio vertès pasiūlymo elementus ir vertės pasiūlymo adaptavimą darbuotojams;

- Pateikti siūlymus tolimesniems empiriniams tyrimams, skirtiems darbdavio vertès pasiūlymo adaptacijai specifinėms tikslinėms grupėms prioritetu laikant darbuotojų išlaikymą organizacijoje.

\section{Darbdavio prekès ženklas}

Darbdavio prekès ženklas - tai ilgalaikè strategija, skirta valdyti potencialių ir esamų darbuotojų bei susijusių subjektų nuostatas apie tam tikrą organizaciją (Backhaus ir Tikko, 2004). Darbdavio prekès ženklo kūrimo siekiamas rezultatas yra atpažistama ir unikali darbdavio tapatybė (Backhaus, 2016). Darbdavio prekès ženklo kūrimo tikslas atskleisti organizaciją kaip darbdavị su jam priskiriamais atributais bei reikšmėmis, kurios identifikuoja organizaciją rinkoje ir daro ją išskirtine konkurentų atžvilgiu. Vienas tiksliausių darbdavio prekès ženklo apibrěžimų, remiantis šios sąvokos pradininkų Ambler ir Barrow (1996) pateikiamas Backhaus ir Tikko (2004) darbuose, kurie darbdavio prekès ženklą apibūdina kaip siūlomų funkcinių, ekonominių ir psichologinių naudų paketą pritraukiant, motyvuojant bei išlaikant esamus ir potencialius organizacijos darbuotojus. Žmogiškujų išteklių valdymo užduotis yra užtikrinti ir skatinti geidžiamos organizacijos reputacijos plètrą, dèl kurios organizacija gali išsiskirti nuo konkurentų, pritraukti talentingus darbuotojus ị savo organizaciją ir juos išlaikyti. Teorijoje, remiantis Ambler ir Barrow (1996), yra ịvardijami trys kriterijai, kuriuos turètų tenkinti darbdavio prekès ženklas: atspindèti realų organizacijos vaizdą, išsiskirti iš konkuruojančių darbdavių bei būti patrauklūs tikslinėms auditorijoms. Darbdavio prekès ženklas taip pat sukuria du svarbius organizacinius vartojimo ịrankius: darbdavio prekès ženklo asociacijas ir lojalumą darbdavio prekès ženklui. Darbdavio prekès ženklo asociacijos - tai mintys ir idejjos, kurias prekès ženklas sukuria vartotojų mąstyme (Aaker, 1997). Šios asociacijos gali nulemti darbdavio prekès ženklo patrauklumo lygị. Pasitelkus žmogiškujų išteklių išorinę rinkodarą, itin svarbu komunikuoti tas asociacijas, su kuriomis darbdavys norètu būti sutapatintas, nes potencialūs darbuotojai dažnai susidaro nuomonę iš šaltinių, kurių pats darbdavys nekontroliuoja (Backhaus, 2016). Tuo tarpu darbuotoju lojalumas darbdavio prekès ženklui yra analogiškas organizaciniam ịsipareigojimui, kuris atskleidžia būsimiems darbuotojams esamų darbuotojų pasitenkinimo lygị darbu bei požymius, kurie juos išlaiko organizacijoje. Lojalumas darbdavio prekès ženklui pasąmoningai paverčia darbuotojus prekès ženklo ambasadoriais (Holbeche ir Matthews, 2012). Būdami prekès ženklo ambasadoriais, darbuotojai įsisavina darbdavio kuriamą ịvaizdị ir projektuoja ši vaizdą būsimiems darbuotojams, klientams ar kitiems suinteresuotiesiems subjektams skleisdami žinutę ne tik darbo metu, bet ir už jo ribų. Taip pat netiesiogiai perduodant darbdavio ịvaizdị bendravimo su organizacijos klientais metu. Tiek teigiama, tiek neigiama patirtis, su kuria susiduria darbuotojas organizacijoje, gali paveikti tai, kaip subjektai suvokia organizaciją kaip darbo vietą. Darbdavio prekès ženklas iš esmès yra organizacijos kultūros atspindys, o jos darbuotojai yra vieni pagrindinių prekès ženklo žinomumo pranešèjų.

Remiantis Lievens, Van Hoye ir Anseel (2007), darbdavio prekès ženklo kūrimo procesas apima tris etapus: pirmajame etape projektuojamas unikalus darbdavio vertès pasiūlymas - tai yra atributai ar nauda, kurie bus siūlomi potencialiems ir esamiems darbuotojams. Vertès pasiūlymas laikomas darbdavio prekès ženklo pažadu darbuotojams apie patirtį, kurią jie gaus prisijungę prie organizacijos (Backhaus, 2016). Pasak Love ir Singh (2011), vertès pasiūlymas yra pagrindinè daugelio organizacijų išskiriama darbdavio prekès ženklo kūrimo proceso dedamoji. Vertès pasiūlymas gali atskleisti organizacijos vidinę kultūrą, produktų ar paslaugų kokybès vertinimus, darbo aplinką, darbuotojų ir vadovų bendravimo kultūrą bei kitus aspektus. Antrajame etape sukurtas vertès pasiūlymas yra perduodamas kai potencialūs darbuotojai prisijungia prie organizacijos. Trečiajame etape yra stebima kaip realiai yra ịgyvendinti vertès pasiūlyme duoti pažadai. Paskutinis etapas literatūroje, deja aptariamas mažiausiai, todèl neabejotinai yra aktuali tyrimų niša. Darbdavio prekès ženklo kūrimo etapuose, pagrindinis dèmesys sutelkiamas i išorinę organizacijos komunikaciją, i potencialių darbuotojų poreikius, jų pritraukimo keliamus iššūkius (Kazdová, 2014). Remiantis Maxwell ir Knox (2009), darbdavio prekès ženklo kūrimo tikslai neturètų būti ịgyvendinami atsižvelgus vien ị ịdarbinimo etapą. Pasak Backhaus ir Tikko (2004) ilgalaikè darbdavio prekès ženklo kūrimo strategija turètų būti skirta palaikyti nuolatinị ịgūdžių srautą organizacijoje.

Darbdavio prekès ženklo kūrimo svarba bei priemonès literatūroje didžiąa dalimi yra orientuotos i potencialių darbuotojų pritraukimą ir labai mažai ị esamų darbuotojų išlaikymą organizacijoje. Nepakankamai kreipiamas dẻmesys ị prekès ženklo gyvavimo ciklo tvarumą organizacijos viduje. Darbdavio prekès ženklo vertès pasiūlymas 
sietinas su potencialių darbuotojų poreikiais, dẻ šių priežasčių nėra aišku, kas darbdavio prekès ženklą daro patrauklų esamų darbuotojų požiūriu. Atlikta labai mažai darbdavio prekės ženklo tyrimų, kurių pagrindinis objektas būtų organizacijoje jau dirbančių darbuotojų nuostatų ir lūkesčių kaitos tyrimai. Nèra aišku koks vertès pasiūlymas formuojamas ilgą laiką dirbantiems organizacijoje darbuotojams.

\section{Darbdavio patrauklumą lemiantys veiksniai}

Žinių visuomenejje darbuotojų igūdžiai ir gabumai tampa vienu iš pagrindinių organizacijos konkurencingumą skatinančių veiksnių. Organizacijos negali ignoruoti žmogiškojo kapitalo svarbos, talentingų darbuotojų pritraukimo bei išlaikymo organizacijoje (Minchington, 2014). Darbdavio prekès ženklo patrauklumas gali daryti įtaką tiek įdarbinimo, tiek specialistų išlaikymo procesams. Nors pradiniame ịdarbinimo etape siekiama pritraukti kandidatus ị konkrečias laisvas pareigas tam tikru metu, organizacijos patrauklumas turi būti nuolatos plètojimas, kad darbdavys taptų pripažintas ir patrauklus tiek vidinëje tiek išorinëje organizacijos aplinkoje. Remiantis Arrehag ir Persson (2014) darbdavio patrauklumas paprastai siejamas su teigiamu darbuotojų vertinimu, kuris turi didžiausią paveikumą darbdavio ịvaizdžiui suinteresuotųjų sąmonejje. Pasak Arrehag ir Persson (2014) patrauklus darbdavys yra tas, kuris gali suteikti darbo ir gyvenimo poreikius atitinkančias darbo sąlygas, pasiūlyti naudingą, įdomų darbą, lūkesčius atitinkantị atlyginimą, sietis su gera organizacijos reputacija. Bakanauskienè, Bendaravičienè ir Barkauskè (2017) taip pat išskiria patrauklios organizacijos požymius: tai organizacijos finansinè padètis, reputacija visuomeneje, prekès ženklo žinomumas, vadovų bei darbuotojų deklaruojami santykiai, darbo specifika bei kuriama darbinè aplinka. Van Hoye, Bas, Cromheecke ir Lievens (2013) išskiria nuoširdžią, atvirą bei inovatyvią darbo aplinką, darbuotojų îvertinimus. Darbdavio patrauklumą ypač lemia geri darbuotojų ir vadovų santykiai, vadovų pasitikèjimas pavaldiniais, padrąsinimai bei įvertinimai už atliktas užduotis, galimybė dalintis turimomis žiniomis bei mokyti kitus taip pat kūrybiškumo skatinimas organizacijoje, darbuotojų pripažinimas bei saugi ir jauki darbo aplinka.

Darbdavio patrauklumas gali daryti įtaką karjeros pradžioje bei tolimesniuose ketinimuose, susijusiuose su darbo vietos keitimu, todèl itin svarbu tikslingai nustatyti, kokios konkrečios naudos darbuotojai tikisi ir puoselèti tai tikslinèse auditorijose. Pasak autorių Lievens ir Slaughter (2016) potencialus darbuotojas ieško vadinamos instrumentinès naudos, kuri susijusi su faktiniais darbo atributais, turinčiais praktinę vertę bei simbolinès naudos, kuri yra susijusi su neturtiniais atributais. Instrumentines naudas, kaip darbo užmokesčio paketas, lankstus darbo grafikas ar vieta, bene visos organizacijos gali skirti labai panašias, todèl ypač svarbios tampa simbolinės naudas, pvz.: organizacijos prestižas, verslo inovacijų siekiai, investicijos ị darbuotojus, darbo kultūra bei kitos, kurios labiau padeda darbdaviui išsiskirti nuo konkurentų nei instrumentiniai atributai (Lievens ir Slaughter, 2016). Išanalizavus mokslinę literatūrą, buvo išskirtas svarbus tyrimo objektas - tai darbdavio vertès pasiūlymas.

Darbdavio vertès pasiūlymas yra darbdavio prekès ženklo kūrimo elementas, kuris komunikuoja tikslinėms grupèms asociacijas susijusias su organizacija bei pasiūlymų rinkinị, kurị organizacija teikia mainais už ịūdžius, galimybes ir patirtị, kuriuos darbuotojas suteikia organizacijai (Headworth, 2015). Darbdavio vertès pasiūlymas yra unikalus atributų ir naudos rinkinys, kuris motyvuos potencialius darbuotojus įsidarbinti organizacijoje, o esamus pasilikti. Prieš pateikiant darbdavio vertès pasiūlymą tikslinèms auditorijoms, vertès pasiūlymas turi atitikti organizacijos realų vaizdą. Tarp to ko potencialus darbuotojas tikisi ir to, ką esamas patiria konkrečioje organizacijoje. Organizacijos, kurios efektyviai dirba formuodamos darbdavio vertès pasiūlymą gali sumažinti metinę darbuotojų kaitą 70 \% (Kropp, 2018), tačiau jei vertès pasiūlymas nèra taikomas esamiems darbuotojams bei po įdarbinimo etapo duoti pažadai nèra išpildomi, tai gali neigiamai paveikti ịsipareigojimą organizacijai ir sukurtas patrauklaus darbdavio ịvaizdis gali sugriūti. Pasak Ambler ir Barrow (1996), vertès pasiūlymą turètų sudaryti funkcinių, ekonominių bei psichologinių naudų paketas. Šis siūlomų naudų paketas vẻliau buvo patobulintas Berthon, Ewing ir Hah (2005). Autoriai sukūrè modelị, vadinamą „EmpAt“ (angl. Employer Attractiveness) skirtą darbdavių patrauklumui įvertinti, kurị sudaro penkios siūlomos vertė:

- Patrauklumo verte yra organizacijos pateikimo būdas, kuris išsiskiria inovatyvia, įdomia, jaudinančia, keliančia iššūkius darbo aplinka, skatinančia bei vertinančia darbuotojų kūrybiškumą, stimuliuojanti darbą. Vidinė organizacijos kultūra atlieka svarbų vaidmenį svarstant apie būsimą darbdavị. Tyrimai rodo, jog potencialūs darbuotojai teikia pirmenybę atviroms, kūrybiškoms, inovatyvioms organizacijoms, kurios nebijo rizikuoti investuodamos i naujas idejjas, produktus ar paslaugas. Prie organizacijos kultūros priskiriami ir tokie elementai kaip darbuotojų nuomonès, įsitikinimai, nuostatos bei organizacijos vertybès, kurios atspindi tiek naujų tiek esamų darbuotojų elgseną organizacijoje (Leovaridis ir Cismaru, 2016). Organizacijos turinčios stiprią inovacijų kultūrą, potencialiems darbuotojams atrodo daug patrauklesnès. Jeigu potencialus ar esamas darbuotojas laikys save novatoriška asmenybe, o organizacija nesuteiks galimybių realizuoti sukauptas idejjas bei vystyti novatorišką savastį, darbuotojas greičiausiai paliks organizaciją. Taip pat remiantis moksline literatūra, teigiama jog asmenys daug labiau motyvuoti dirbti aplinkoje, kurioje suteikiama smalsumo galimybè, idèjų bei asmeninių iššūkių skatinimas. Organizacijos patrauklumo suvokimui taip pat didelę ịtaką daro ir turimos žinios apie organizaciją, darbdavio prekès ženklo asociacijos (Backhaus ir Tikko, 2004). Jeigu darbdavio prekès ženklas yra žinomas, 
populiarus, potencialus darbuotojas gali organizaciją laikyti patraukliu darbdaviu, kadangi dèl populiarumo laiko ją sèkminga.

- Socialinè vertè siejama su organizacijos galimybėmis pasiūlyti draugišką kolektyvą, gerus santykius su kolegomis. Socializacija yra vienas iš faktorių kuomet daroma įtaka komandiniam darbui. Socialiniai poreikiai rodo norą būti priimtiems kitų žmonių, todèl siekiantiems sustiprinti komandinị darbą, reikia skatinti darbuotojus bendrauti ne tik formaliai, bet ir neformaliu būdu tarpusavyje. Taip pat komandinis darbas palengvina dalijimąsi idèjomis, žiniomis ir ištekliais, kurie gali padidinti inovatyvių projektų sẻkmę ir komandini darbuotojų kūrybiškumą. Socialinis organizacijos kapitalas taip pat svarbus atributas, kuriuo metu kuriamas santykių ir ryšių tinklas su darbuotojais ir vadovais. Tiesioginis prieinamumas prie vadovo, atviras bendravimas bei prieinamumas darbuotojams sukuria socialinius ryšius, kurie paskatina bendruomeniškumą, pasitikèjimą, organizacijos narių kooperaciją.

- Ekonominè vertė pasireiškia darbdavio galimybėmis suteikti tam tikrą atlyginimą, priedų sistemą. Ekonominès vertès svarbą, aptaria autoriai Lee ir Hanna (2015). Kiekvienas darbuotojas nori gauti jo pastangas įvertinantị atlyginimą ir darbdavių supratimo apie šios vertès svarbą, nes tai yra viena esminių priežasčių, kodèl jie dirba. Pinigai yra nepakeičiamas atlygis, kuris darbuotojus veikia ir kaip motyvacinis faktorius. Jie turi nepaprastą galią pritraukti, išlaikyti bei motyvuoti siekti aukštesnių rezultatų. Prie ekonominès vertès gali būti priskiriamos ir nuolaidos paslaugoms ar prekèms organizacijos viduje bei išorèje, ịvairūs draudimo paketai ir pan.

- Saviraiškos vertè tai investicijos ị darbuotojus, jų igūdžiu taikyti žinias bei mokyti kitus, mentorystès programas. Investicijos $\mathfrak{i}$ darbuotojus organizacijai atneša ịsipareigojimą darbdaviui. Galimybė atskleisti savo talentus, ịūdžių bei žinių panaudojimas, darbdavio pasitikèjimas skirti užduotis skatina darbuotojų pasitenkinimą darbu, motyvaciją dirbti bei gali pagerinti darbo kokybę. Mentorystès programos skirtos atskleisti darbuotojų sukauptas žinias bei pasidalinti jomis su kitais taip pat išreiškiant save. Organizacijos skatinančios mentorystès programas taip pat sukuria teigiamą ịvaizdi apie darbdavị, gali padidinti esamų darbuotojų produktyvumą, paskatinti atsirasti naujoms idejoms, pasitikèti savo jègomis ir įkvėpti būsimus ar naujus darbuotojus.

- Savirealizacijos verté susijusi su karjeros galimybėmis, darbuotojų pasiekimų ịvertinimu, ji suteikia galimybę darbuotojui realizuoti save pasirinktoje organizacijoje. Vienas iš kriterijų - karjeros galimybès, kurių rezultatas - paaukštinimas. Paaukštinimas ne tik skatina asmeninį tobulejimą, bet ir socialinio statuso pagerejjimą, be to skatina naujų ịgūdžių atsiradimą. Kitas svarbus kriterijus - pripažinimas sietinas su darbuotojo veiklos įvertinimu, jo tam tikro statuso organizacijoje suteikimu. Prie pripažinimo būtų galima priskirti ir tam tikras vadovo užduotis pavestas atlikti darbuotojui, kurios gali pakelti darbuotojo savivertę, įkvèpti, suteikti motyvacijos. Taip pat svarbu paminèti darbuotojų įsitraukimą organizacijos sprendimų prièmime.

Ivvertinus naujausias tendencijas, Dabirian, Kietzmann ir Diba (2016) minėtas vertes papildo dar dvejomis (žr. 1 paveikslą):

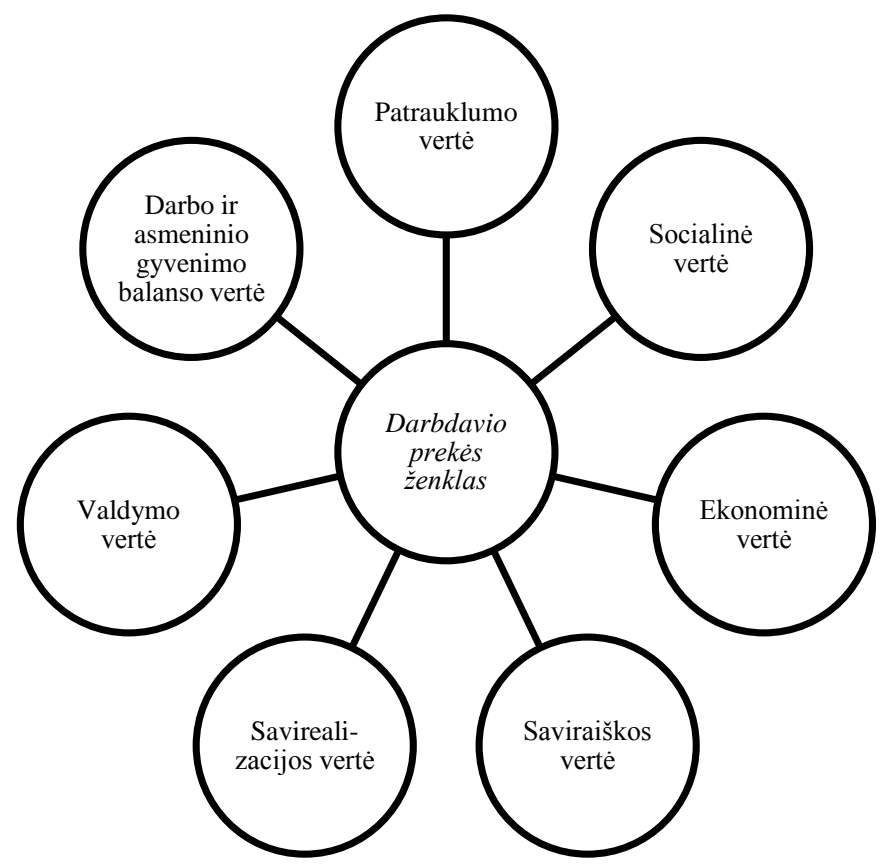

1 paveikslas. Darbdavio prekès ženklo teikiamos vertès (sudaryta remiantis Berthon, Ewing ir Hah (2005), Dabirian, Kietzmann ir Diba (2016)) 
- Valdymo verté atskleidžia kiek darbuotojams yra priimtinas vadovų reitingas ir vadovavimo stilius. Svarbu, kad vadovo vertybès atitiktų organizacijos vertybes. Darbuotojas neretai pasirenka darbdavị dẻl jam artimų vertybių. Vadovo vadovavimo stilius gali daryti tiek teigiamą, tiek neigiamą įtaką darbuotojų įsitraukimui, o visa valdymo struktūra turètų užtikrinti efektyvų ir sklandų bendravimą. Tyrimai rodo jog darbuotojams labai svarbus vadovų draugiškas tonas, bendravimas neformalioje aplinkoje, politikos teisingumas ir skaidrumas, suteikta darbuotojams galimybė dalyvauti priimant sprendimus, ką dažnai lemia vadovo vadovavimo stilius. Tyrimai susiję su vadovų emocijų raiška darbuotojams, parodė jog teigiamos vadovo emocijos gali sumažinti darbuotojų baimę neįtikti vadovui, todèl jie jaučiasi daug laisvesni ir noriai gali pasiūlyti naujų idejjų nebijodami būti kritikuojami. Vadovų emocinio intelekto tyrimai atskleidè, kad vadovų išreiškiamos teigiamos emocijos, gali padidinti darbuotojų įsitraukimą i darbą bei ugdyti motyvaciją (Tumasjan et al., 2019). Be to, pozityvesnes emocijas palaikantys vadovai gali efektyviau palengvinti vadovo ir pavaldinio santykius ir skatinti darbuotojų motyvaciją. Unikali vadovo asmeninè patirtis, autoritetas, jo biografija gali tapti svarbia organizacijos siūloma verte, kuri yra itin svarbi jauniems, profesinę karjerą pradedantiems darbuotojams.

- Darbo ir asmeninio gyvenimo balanso vertè yra darbdavio gebejjimas suteikti darbuotojui sąlygas derinti asmeninį gyvenimą su darbu. Darbo ir asmeninio gyvenimo balanso verte siejama su lanksčiu darbo grafiku, darbo organizavimo tvarka, šeimos atostogomis, darbuotojų pagalba bei konsultavimo programomis, vaiko priežiūros paslaugomis siūlant lanksčias darbo valandas ir kitų darbo ir asmeninio gyvenimo balansą užtikrinančių priemonių. Dèl darbo ir asmeninio gyvenimo nesuderinamumo gali kilti stresas, nukentèti darbo kokybè, kilti pasipiktinimas arba nukentèti santykiai su šeima.

Šalia darbdavio kuriamo verčių pasiūlymo pritraukti potencialiems darbuotojams, turètų būti sutelkiamas dèmesys ir ị esamų darbuotojų išlaikymą. İdarbinimo strategijos siekiant pritraukti darbuotojus yra trumpalaikės, reaguojančios ị tai, kur atsiranda laisvų darbo vietų, kai tuo tarpu išlaikymo strategija yra ilgalaikè ir turètų būti skirta palaikyti stabilų kompetencijų srautą organizacijoje. Vertès atributų prioritetų nustatymas gali skirtis atsižvelgiant i skirtingas organizacijų kultūras bei demografines charakteristikas. Vienas labiausiai naudojamų teorinių modelių išlieka Berthon, Ewing ir Hah (2005) pasiūlytas verčių modelis, papildytas Dabirian, Kietzmann ir Diba (2016). Šio modelio taikymo efektyvumas organizacijų praktikoje nèra tirtas. Kyla klausimas kaip ši modelị panaudoti siekiant išlaikyti darbuotojus. Kokie požymiai turètų skatinti darbuotojus pasilikti organizacijoje? I ką turètų atkreipti dėmesį darbdavys norėdamas pritaikyti šias vertes skirtingoms darbuotojų grupėms?

\section{Vertės pasiūlymo elementų empirinių tyrimų kryptys}

Žmonių išteklių valdymo specialistai tik neseniai pripažino darbdavio prekès ženklo vertès pasiūlymo svarbą ir poveikį darbuotojų įdarbinimo bei išlaikymo etapuose. Kaip jau minèta anksčiau, vertès pasiūlymas, tai organizacijos mainai darbuotojams už igūdžius, galimybes ir patirtis, kuriuos darbuotojas suteikia organizacijai (Minchington, 2014). Kurdamas vertès pasiūlymą darbdavys pirmiausia turètų išskirti tikslinę auditoriją kuriai būtų taikomas vertès pasiūlymas, išsiaiškinti tikslinès auditorijos lūkesčius, poreikius, tai yra atlikti psichografinị bei demografinị tyrimus. Žinodamas tikslinès auditorijos lūkesčius, darbdavys turètų gebèti tikslingai suformuoti vertès pasiūlymą, kuris suteiktų darbuotojui ieškomos naudos. Remiantis literatūros analize norint efektyviai panaudoti verčių pasiūlymo modelį, kiekvienai vertei turètų būti priskiriami būdingi kriterijai, kuriais organizacija galètų vadovautis atsižvelgus ị tikslinès auditorijos lūkesčius.

Dauguma žmogaus elgesio ypatumų ir ji lemiančių veiksnių užfiksuota ịvairiuose tekstuose, dokumentuose, kurie gali teikti objektyvios informacijos vienu ar kitu klausimu (Kardelis, 2016). Todèl empiriniam tyrimui atlikti pasirinktas turinio analizės metodas. Norint išsiaiškinti, kokius vertès pasiūlymus darbdavys pozicionuoja išorinëje komunikacijoje, šiuo atveju socialiniuose tinkluose, siekiant patikrinti verčių pasiūlymo modelio efektyvumą, pasirinkta atlikti medijų turinio analizę. Turinio analizès tikslas yra atrasti tekste tam tikrus prasminius vienetus, tirti ryšį tarp jų ir visos bendros informacijos. Šio tyrimo metodo naudojimas visų pirma leis atskleisti, susisteminti ir apibendrinti tiriamą informaciją, o tyrimo rezultatai leis identifikuoti tolimesnes tyrimo kryptis. Turinio analizė yra formalizuotas verbalinės informacijos tyrimo būdas, numatantis jos turinio vertinimą ieškant požymių, kurie svarbūs tyrèjui.

Taigi išskirtos 7 vertès: patrauklumo (keliantis iššūkius darbas, inovatyvi, kūrybiška darbinè aplinka, socialiai atsakinga organizacija), socialine (draugiškas kolektyvas, komandinio darbo skatinimas, palanki darbo aplinka, neformalūs renginiai), ekonomine (skatinimas premijomis už darbo rezultatus, atlyginimas, draudimo paketai, nuolaidos paslaugoms bei prekèms), saviraiškos (karjeros galimybės, darbuotojų nuopelnų pripažinimas, veiklos ịvertinimai), savirealizacijos (sukauptų žinių taikymas, mokymų bei mentorystės programos, idèjų realizavimas), valdymo (darbuotojo teisè spręsti pasilikti ar ne organizacijoje dèl jo vadovo vadovavimo stiliaus bei visos organizacijos valdymo politikos, vadovo kaip lyderio pozicija) bei darbo ir asmeninio gyvenimo balanso verte (darbdavio suteikiamos darbuotojui sąlygos derinti asmeninị gyvenimą su darbu) ir remiantis literatūros analize kiekvienai vertei priskirti kriterijai (žr. 1 lentelę), kuriais vadovaujantis bus atliktas tyrimas.

Tyrimui atlikti buvo panaudota 2017-2018 metais organizuotų „Geidžiamiausio darbdavio“ rinkimų dalyvių sąrašas. Iki 2018 m. rinkimai buvo vykdomi viešai, visuomenei balsuojant ir vertinant pagal pasirinktą kriterijų: 
konkurencingas atlygis, ịdomus ir prasmingas darbas, motyvacijos ir karjeros sistemų skaidrumas bei geras darbdavio įvaizdis. Nuo $2018 \mathrm{~m}$. darbdavys vertinamas pagal tris rodiklių grupes: ịmonès stabilumas, atlygis ir reputacija. Darbdavio stabilumas buvo vertinamas pagal įmonès finansinius rodiklius bei darbuotojų skaičiaus pokytị. Darbdavio mokamas atlygis vertinamas pagal vidutinio darbo užmokesčio $2017 \mathrm{~m}$. dydị bei jo santykị su vidutiniu užmokesčiu ta pačia veikla užsiimančiose įmonėse Lietuvoje. Reputacija vertinama dvejais rodikliais. Pirma, kaip dažnai įmonė buvo paminèta karjeros portalo cv.lt vartotojų užsakomuosiuose darbo skelbimuose. Antra vertinimo dalis - UAB „Mediaskopas“ atliktas įmonès žinomumo/reputacijos įvertinimas.

1 lentelè. Verčių pasiūlymams būdingi kriterijai (sudaryta autorių remiantis Lievens ir Slaughter (2016), Lievens, Van Hoye ir Anseel (2007), Dabirian, Kietzmann ir Diba (2016), Berthon, Ewing ir Hah (2005))

\begin{tabular}{|c|c|}
\hline Vertè & Kriterijus \\
\hline Patrauklumo verte & $\begin{array}{l}\text { Socialinè organizacijos atsakomybė } \\
\text { Inovatyvūs darbo organizavimo sprendimai } \\
\text { Darbdavio prekės ženklas } \\
\text { Organizacijos kultūra }\end{array}$ \\
\hline Socialinè vertè & $\begin{array}{l}\text { Saugumas } \\
\text { Draugiška aplinka } \\
\text { Neformalaus bendravimo skatinimas } \\
\text { Socialinis organizacijos kapitalas }\end{array}$ \\
\hline Ekonominé vertè & $\begin{array}{l}\text { Atlyginimai } \\
\text { Priedai } \\
\text { Draudimo paketai } \\
\text { Nuolaidos prekėms ir paslaugoms }\end{array}$ \\
\hline Saviraiškos vertè & $\begin{array}{l}\text { Investicijos ị darbuotojus } \\
\text { Mentorystė }\end{array}$ \\
\hline Savirealizacijos vertè & $\begin{array}{l}\text { Karjeros galimybès } \\
\text { Pripažinimo ir delegavimo praktika } \\
\text { Igaliojimo praktika } \\
\text { Dalyvavimas sprendimų prièmime }\end{array}$ \\
\hline Valdymo vertè & $\begin{array}{l}\text { Vadovų vadovavimo stilius } \\
\text { Organizacijos valdymo struktūra } \\
\text { Vadovų profiliai ir patirtis }\end{array}$ \\
\hline Darbo ir asmeninio gyvenimo balanso vertè & $\begin{array}{l}\text { Lankstus darbo grafikas } \\
\text { Šeimos atostogos } \\
\text { Darbuotojų pagalbos programos } \\
\text { Vaikų priežiūra ir ugdymas }\end{array}$ \\
\hline
\end{tabular}

Buvo atrinkti 10 darbdavių: „,SEB Bankas“, „Telia Lietuva“, „Cirkle K Lietuva“, „Ruptela“, „Danske Bank“, „Western Union Processing Lithuania“ (toliau WU), „Girteka Logistics“, „Bitè Lietuva“, „Felit“" ir „Vičiūnai Group“.

2019 metų sausio - lapkričio mėn., buvo atlikti šių darbdavių profilių socialinėse medijose tyrimai siekiant gauti kuo tikslingesnę, naujesnę, išsamesnę informaciją.

Atlikus empirinị tyrimą, taikant turinio analizès metodus išryškèjo pagrindinès siūlomos vertès, kurias darbdaviai pateikia potencialiems darbuotojams (žr. 2 lentelę). Lietuvoje tarp ,geidžiamiausiais“ išrinktų darbdavių vieningai vyrauja patrauklumo, socialinè, saviraiškos bei savirealizacijos vertès, komunikuojamos per socialinius tinklus Facebook, Linkedin bei Instagram. Valdymo vertę išskiria 6 iš 10 darbdavių. Ekonominę vertę išskyre 1 iš 10 darbdavių, darbo ir asmeninio gyvenimo balanso vertę - 1 iš 10 darbdavių. Vis daugiau teorijoje nagrinejama darbo ir asmeninio gyvenimo balanso bei ekonominè vertè nėra efektyviai komunikuojamos socialiniuose tinkluose. Tikètina, kad ekonominè vertè gali būti ịvardijama kaip motyvacinis veiksnys siekiantis išlaikyti darbuotojus organizacijoje bei asmeninio pokalbio su naujais priimamais darbuotojais metu. Darbdaviai vis dar mažai arba visai nekomunikuoja darbo ir asmeninio gyvenimo balanso vertybių, kurios šiuolaikiniam žmogui yra ypatingai svarbios. Ši neišnaudota niša galètų ypač padidinti darbdavio patrauklumą.

Atliktas tyrimas padejjo ịvertinti objektą remiantis vien išorine organizacijų komunikacija. „Geidžiamiausių darbdavių“ pasiūlymai, siekiant pritraukti, išlaikyti ir sukurti patrauklų darbdavio prekès ženklą yra vienodi, neišsiskiriantys, todèl rinkoje nebelieka konkurencinio organizacijų pranašumo: tai patvirtina pagrindinę tyrimo hipotezę. Darbdavio prekès ženklo adaptavimo skirtingoms darbuotojų grupèms požymiai nèra ryškūs, komunikacijos turinys neišskiriamas skirtinguose kanaluose (Facebook, Linkedin, Instagram), kurie potencialiai yra skirti skirtingoms tikslinėms grupėms, todèl darbdavio prekès ženklas neveikia kaip efektyvus ịrankis. Kuriant verčių pasiūlymą socialiniuose tinkluose nẻra atsižvelgiamą ị vertès pasiūlymo žinutę. Vertès pasiūlymas nẻra 
formuojamas pagal kanalą bei jo tikslinę auditoriją. Kai kurios organizacijos yra linkusios dalintis ta pačia informacija visuose kanaluose kas iš dalies patvirtina ir antrają tyrimo hipotezę, tačiau akivaizdu, kad išvadoms formuoti būtini išsamūs gilesni empiriniai tyrimai. Tai leidžia daryti išvadą, jog tema yra aktuali ir pirmauja kaip būsimų tyrimų kryptis.

2 lentelè. Empirinio tyrimo rezultatai (sudaryta autorių)

\begin{tabular}{|c|c|c|c|c|c|c|c|c|c|c|}
\hline & $\begin{array}{l}\text { SEB } \\
\text { Bankas }\end{array}$ & $\begin{array}{c}\text { Telia } \\
\text { Lietuva }\end{array}$ & $\begin{array}{l}\text { Cirkle } \\
\text { K } \\
\text { Lietuva }\end{array}$ & Ruptela & $\begin{array}{l}\text { Danske } \\
\text { Bank }\end{array}$ & WU & $\begin{array}{l}\text { Girteka } \\
\text { Logistics }\end{array}$ & $\begin{array}{c}\text { Bitė } \\
\text { Lietuva }\end{array}$ & Felit & $\begin{array}{l}\text { Vičiūnai } \\
\text { Group }\end{array}$ \\
\hline \multicolumn{11}{|c|}{ Patrauklumo } \\
\hline $\begin{array}{l}\text { Socialinė } \\
\text { organizacijos } \\
\text { atsakomybė }\end{array}$ & + & + & + & + & + & + & + & + & + & + \\
\hline $\begin{array}{l}\text { Inovatyvūs darbo } \\
\text { organizavimo } \\
\text { sprendimai }\end{array}$ & + & + & & + & + & + & + & + & + & + \\
\hline $\begin{array}{l}\text { Darbdavio prekès } \\
\text { ženklas }\end{array}$ & + & + & & + & + & + & + & + & + & + \\
\hline Organizacijos kultūra & + & & & & & + & & + & & \\
\hline \multicolumn{11}{|c|}{ Socialinė } \\
\hline $\begin{array}{l}\text { Socialinis } \\
\text { organizacijos } \\
\text { kapitalas } \\
\end{array}$ & & + & + & + & + & + & + & + & + & + \\
\hline Saugumas & & + & & & & & & & & \\
\hline Draugiška aplinka & + & + & + & + & + & + & + & + & + & \\
\hline $\begin{array}{l}\text { Neformalaus } \\
\text { bendravimo } \\
\text { skatinimas }\end{array}$ & + & + & & + & + & + & + & + & + & \\
\hline \multicolumn{11}{|c|}{ Ekonominè } \\
\hline Atlyginimas & & & & & & & & & & \\
\hline Priedai & & & & & & & + & & & \\
\hline \multirow{2}{*}{\multicolumn{11}{|c|}{$\begin{array}{l}\text { Nuolaidos prekems ir } \\
\text { paslaugoms }\end{array}$}} \\
\hline & & & & & & & & & & \\
\hline \multicolumn{11}{|c|}{ Saviraiškos } \\
\hline $\begin{array}{l}\text { Investicijos i } \\
\text { darbuotojus }\end{array}$ & + & + & + & + & + & + & + & + & + & \\
\hline Mentorystė & + & + & + & & & + & + & + & + & + \\
\hline \multicolumn{11}{|c|}{ Savirealizacijos } \\
\hline Karjeros galimybės & + & + & & & + & + & + & & & + \\
\hline $\begin{array}{l}\text { Pripažinimo ir } \\
\text { delegavimo praktika }\end{array}$ & + & + & + & + & + & + & + & & + & + \\
\hline Igaliojimo praktika & & + & & & + & & & & & \\
\hline \multicolumn{11}{|l|}{$\begin{array}{l}\text { Dalyvavimas } \\
\text { sprendimų prièmime }\end{array}$} \\
\hline \multicolumn{11}{|c|}{ Valdymo } \\
\hline $\begin{array}{l}\text { Vadovų vadovavimo } \\
\text { stilius }\end{array}$ & & & & & + & + & & & & \\
\hline $\begin{array}{l}\text { Organizacijos } \\
\text { valdymo struktūra }\end{array}$ & + & + & + & + & + & & + & & & + \\
\hline $\begin{array}{l}\text { Vadovu profiliai ir } \\
\text { patirtis }\end{array}$ & + & + & & & + & + & & + & & \\
\hline \multicolumn{11}{|c|}{ Darbo ir asmeninio gyvenimo balanso } \\
\hline \multicolumn{11}{|l|}{$\begin{array}{l}\text { Lankstus darbo } \\
\text { grafikas }\end{array}$} \\
\hline Šeimos atostogos & & & & & + & & & & & \\
\hline \multicolumn{11}{|l|}{$\begin{array}{l}\text { Darbuotoju pagalbos } \\
\text { programos }\end{array}$} \\
\hline $\begin{array}{l}\text { Vaikų priežiūra ir } \\
\text { ugdymas }\end{array}$ & & & & & & & & & & \\
\hline
\end{tabular}




\section{Išvados ir pasiūlymai tolimesniems empiriniams tyrimams}

Mokslinėje literatūroje itin mažai dèmesio skiriama vertès pasiūlymo pritaikymui, kuris galètu padèti organizacijoms veiksmingai kurti darbdavio prekès ženklą siekiant ne tik pritraukti potencialius darbuotojus ị savo organizaciją, bet išlaikyti juos ilgesnị darbo laiką organizacijoje. Pilotinio empirinio tyrimo rezultatai rodo, kad darbdavio prekès ženklo vertès pasiūlymas yra daugelio organizacijų vienodas ir nepritaikytas pozicionavimui. Galima teigti, kad standartinis vertès pasiūlymo paketas jau nebėra tinkamas naudoti šiandieninèje rinkoje. Darbdavio prekès ženklo tikslingai kuriamas vertès pasiūlymas turètų koreliuoti tiek vidinèje tiek išorinèje komunikacijoje, tačiau būtina ji adaptuoti atsižvelgiant i skirtingas darbuotojų grupes, jų darbo trukmę organizacijoje. Išskiriami verčių pasiūlymo kriterijai, kurie buvo naudojami atliekant turinio analizę, turètų būti papildyti naujais dideli dèmesị skiriant skirtingiems darbuotojų profesiniams bei asmeniniams gebėjimams, poreikiams ir jų lūkesčiams, t.y. vertès pasiūlymas negali būti taikomas visiems vienodas, būtinas tikslinių grupiụ poreikių ịvertinimas modifikuojant vertės pasiūlymą. Tikslingai naudojamas darbdavio prekès ženklas gali padèti sumažinti darbuotojų kaitą, sustiprinti organizacijos identitetą, patrauklumą, padidinti visos organizacijos našumą. Sukurtas vertès pasiūlymas tam, kad veiktų efektingai taip pat turètų būti pritaikytas ne tik vidinei, tačiau ir išorinei komunikacijai. Organizacijos, naudojančios socialinių medijų kanalus, turètų atsižvelgti ị socialinių kanalu specifiškumą bei skleisti informaciją skirtinguose kanaluose adaptuojant žinutės formatus vertėms iškomunikuoti. Būtų tikslinga atlikti empirinị tyrimą siekiant nustatyti kaip keičiasi darbuotojų lūkesčiai augant darbuotojo patirčiai organizacijoje bei didèjant darbuotojo ịsitraukimui joje. Koks vertès pasiūlymas atitiktu darbuotojo lūkesčius parenkant konkrečia darbuotojų kategoriją ar segmentuojant juos pagal darbo laiką organizacijoje. Toks tyrimas suteiktų naujų ižvalgų kaip patobulinti darbdavio prekės ženklo veiksmingumą išlaikant darbuotojus organizacijoje.

\section{Literatūra}

Aaker, J. A. (1997). Dimensions of brand personality. Journal of Marketing Research, 34(3), 347-356. https://doi.org/10.1177/002224379703400304

Ambler, T., \& Barrow, S. (1996). The employer brand. The Journal of Brand Management, 4(3), $185-206$. https://doi.org/10.1057/bm.1996.42

Arrehag, P., \& Persson, S. (2014). Describing the relationship between Employer Attractiveness and Internal Brand Equity: A quantitaive single cross-sectional study (Bachelor Thesis). Linnaeus University.

Backhaus, K. (2016). Employer branding revisited. Organization Management Journal, 13(4), $193-201$. https://doi.org/10.1080/15416518.2016.1245128

Backhaus, K., \& Tikoo, S. (2004). Conceptualizing and researching employer branding. Career Development International, 9(5), 501-517. https://doi.org/10.1108/13620430410550754

Bakanauskienè, I., Bendaravičienè, R., \& Barkauskè, L. (2017). Features of employer attractiveness on Lithuania business organizations: Employees' perceptions. Management of Organizations: Systematic Research, 77(1), 7-23. https://doi.org/10.1515/mosr-2017-0001

Berthon, P., Ewing, M., \& Hah, L. L. (2005). Captivating company: Dimensions of attractiveness in employer branding. International Journal of Advertising, 24(2), 151-172. https://doi.org/10.1080/02650487.2005.11072912

Dabirian, A., Kietzmann, J., \& Diba, H. (2016). A Great place to Work!? Understanding crowdsourced employer branding. Bussiness Horizons, 60(2), 197-205. https://doi.org/10.1016/j.bushor.2016.11.005

Headworth, A. (2015). Social media recruitment: How to successfully integrate social media into recruitment strategy. Kogan Page Publishers.

Holbeche, L., \& Matthews, G. (2012). Engaged: Unleashing your organization's potential through employee engagement. John Wiley \& Sons. https://doi.org/10.1002/9781119208167

Kardelis, K. (2016). Moksliniu tyrimu metodologija ir metodai. Mokslo ir enciklopedijų leidybos centras.

Kazdová, A. (2014). Even candidates build your brand. Modern Management, 49(10), 61-63.

Kropp, B. (2019). Strangthen Your Employee Value Proposition. Gartner.

Lee, J. M., \& Hanna, S. D. (2015). Savings goals and savings behavior from a perspective of Maslow's hierarchy of needs. https://doi.org/10.1891/1052-3073.26.2.129

Leovaridis, C., \& Cismaru, M. D. (2016). Characteristics of organizational culture and climate in knowledge - Intensive organisations. Romanian Journal of Communication and Public Relations, 16(2), 35-56. https://doi.org/10.21018/rjcpr.2014.2.181

Lievens, F., \& Slaughter, E. J. (2016). Employer image and employer branding: What We know and what we need to know. Annual Review of Organizational Psychology and Organizational Behavior, 3, 407-440. https://doi.org/10.1146/annurev-orgpsych-041015-062501

Lievens, F., Van Hoye, G., \& Anseel, F. (2007). Organization identity and employer image: Towards a unifying framework. British Journal of Management, 18(1), 45-59. https://doi.org/10.1111/j.1467-8551.2007.00525.x

Love, L. F., \& Singh, P. (2011). Workplace branding: Leveraging human resources management practices for competitive advantage through "best employer" surveys. Journal of Business and Psychology, 26(2), 175-181. https://doi.org/10.1007/s10869-011-9226-5 
Maxwell, R., \& Knox, S. (2009). Motivating employees to "Live The Brand": A comparative case study of employer brand attractiveness within the firm. Journal of Marketing Management, 25(9-10), 893-907. https://doi.org/10.1362/026725709X479282

Minchington, B. (2014). Who must lead employer branding? HR Future, 9, 14-17.

Tumasjan, A., Kunze, F., Bruch, H., \& Welpe, M. I. (2019). Linking employer branding orientation and firm performance: Testing a dual mediation route of recruitment efficiency and positive affective climate. Human Resource Management, 59(1), 83-99. https://doi.org/10.1002/hrm.21980

Van Hoye, G., Bas, T., Cromheecke, S., \& Lievens, F. (2013). The instrumental and symbolic dimensions of organizations' image as an employer: A large-scale fields study on employer branding in Turkey. Applied Psychology, 62(4), 543-557. https://doi.org/10.1111/j.1464-0597.2012.00495.x

\title{
ADAPTATION OF THE VALUE PROPOSAL TO EMPLOYEE TARGET GROUPS IN THE CONTEXT OF EMPLOYER BRANDING
}

\section{Gerda BERNATAVIČIŪTĖ, Asta RADZEVIČIENĖ}

\begin{abstract}
Employer branding is an effective strategic instrument to attract and retain employees within the organization. In an effort to differentiate itself from its competitors and become an employer of choice, the organization forms a value proposition, which is an integral part of employer's brand. However, the empirical pilot study revealed, that value proposition used by employer is designed almost identically by all the organizations involved in the study and no longer works as a tool of positioning and differential ties. Most previous studies on employer branding had been focused on the attracting and hiring phase. For this reason, little is known about what makes an employer brand attractive to existing employees. In addition to the recruitment phase, the employer should strive to create effective, creative and productive human potential within the organization. Taking into account the professional and personal profiles of different groups of employees and their needs, adapting the value proposition for their needs would increase the employer's brand effectiveness and bring long-term benefits to the organization. Adaptation of the value proposition for existing employees has been investigated in this research.
\end{abstract}

Keywords: Employer branding, value proposition, employee engagement, employee retention, human resource management, organization image. 